\title{
Astro-Meteorological Rainfall Prediction and Validation for Monsoon 2018 in Gujarat, India
}

\author{
V.B. Vaidya ${ }^{1 *}$, Suvarna Dhabale ${ }^{1}$, K.S. Damle ${ }^{1}$, L.D. Chimote ${ }^{2}$ and M.S. Kulshreshtha ${ }^{1}$ \\ ${ }^{1}$ Anand Agricultural University, Anand - 388 110, Gujarat, India \\ ${ }^{2}$ Astrometeorologist, Dombivali, Mumbai, (M.S), India \\ *Corresponding author
}

\section{Keywords \\ Astro-Meteorology, Monsoon Research \\ Almanac, \\ Nakshatra, Rainfall \\ Projection, Skill \\ Score \\ Article Info \\ Accepted: \\ 18 April 2019 \\ Available Online: \\ 10 May 2019}

\section{A B S T R A C T}

Based on astrology, Anand Agricultural University, Anand prepared Nakshatra-Charan wise forecast for four agro-climatic zones of Gujarat from 2005 and 2006. District wise daily forecast was given by AAU's Monsoon Research Almanac from 2007 to 2012. During 2018, daily rainfall was predicted for 19 districts of Gujarat covering all four zones. During 2018, overall monsoon rainfall (June to October) predicted above normal by $23 \%$ for the state as a whole except for Kutch (-0.5\%), Panchmahal (-6.3\%) and Mahisagar $(-37 \%)$ districts during June to October 2018. Chances of getting pre-monsoon and postmonsoon rain at many places during May and November 2018 were also predicted. There was less rainfall in June 2018 ( $-61 \%$ for the state as a whole) and highest rainfall had occurred in South Gujarat, i.e. $+16.7 \%$, followed by Saurashtra with $+34.7 \%$. Between June and September, September will get the highest amount of rainfall $(+75.8 \%$ followed by August $(65.1 \%)$. In October month it was predicted more rainfall but didn't occur. The validation of rainfall forecast on Yes/No basis indicated that average accuracy was $60 \%$ from June to October for a state as a whole. Among the four regions, average accuracy was highest in South Gujarat (72.1\%) and lowest in North Gujarat (53.1\%) for the year 2018.

\section{Introduction}

These Astro-meteorological techniques were used for weather forecasting of Gujarat State. Gujarat state receives an annual rainfall of $828.0 \mathrm{~mm}$ in 35 rainy days with a coefficient of variation of $50 \%$. Giant spatial and temporal variation in the rain of the Gujarat state (Anonymous, 2000). The low rainfall areas receiving less than $500 \mathrm{~mm}$ rainfall are comprised of Kutch district and western parts of Banaskantha and Patan district and parts of Jamnagar, Rajkot and Surendranagar districts.
These are also characterized by the arid climate. The heavy rainfall $(>1000 \mathrm{~mm})$ receiving regions (Dang, Valsad, Navsari, and Surat districts) are characterized as subhumid climate. The other parts of the state receive rainfall between 500 and 1000 millimeter and usually fall into the semi-arid climate (Shekh, 1989).

Anand Agricultural University has prepared almanac predicting district wise daily rainfall from monsoon 2007 to 2012. Again an attempt was made for preparation of almanac- 
2018 for 19 districts of Gujarat. The daily rainfall was predicted for the farming community as well as planners. The actual and predicted rainfall was then studied for its reliability.

It is believed that the village astrologers are correct for predicting weather condition which is highly reliable. The most important aspect regarding our ancient scripture is that future weather of the coming year together can be predicted (Angchok et al., 2004). According to Iyengar (2009), year to year variation of Indian Rains is delineated qualitative in our ancient Sanskrit texts. It has left its imprints in all types of literature starting from the Rigveda. Vedic traditions had a group of information that 'we will know quite we will tell'. They are typically established, dispersed, agreed upon and tested among the local specific livelihood and resource-dependent communities (Santha et al., 2010). India's Monsoon starts from Kerala, the golden shower tree (KaniKonnu) blossoms in plenty, about 45 days before the beginning of monsoon (Pisharoty, 1993; Kanani and Pastakia, 1999). Agriculturalists in Kerala assume that heavy rainfall will bring very warm summers. They anticipate significant rain within a few hours if the sky attains a dark color- 'as dark because of the crow's egg' (Kanani and Pastakia, 1999). It is found that the winter monsoon thunderclouds usually give the impression when 'clouds are over the pounding shed' which is built at the northwest corner of the house according to Vaastu and it rains (Nair, 2004). Similar such techniques of observations are also found in several distinct parts of the country. In Saurashtra, farmers believe that drought occurs if 'the velocity of wind is low during Margashirsha constellation', accompanied by the absence of high heat during the Rohini' (Kanani et al., 2004) (Table 1). There are some of the main native techniques and ways of rainfall prediction throughout the country
(Pisharoty, 1993; Kanani and Pastakia, 1999 and Santha, 2010). Table 2 showed that different areas in India have different traditional practices of rainfall prediction (Pisharoty, 1993; Kanani and Pastakia, 1999). Table 3 showed the Indigenous skill of the tribal community predicate climate (Pareek, 2011).

\section{Materials and Methods}

\section{Preparation of Monsoon Research Almanac-2018}

For the present study 19 stations of Gujarat was selected then it was compared with projected rainfall made by Astrological theories with actual rainfall. The work on preparation of astro-meteorological predictions for 2018 was started late, after formation of committee to prepare Monsoon Research Almanac by AAU, hence it was done for 19 districts of Gujarat covering all four regions of Gujarat viz. Middle Gujarat (8 districts), Saurashtra (3 districts), North Gujarat (4 districts) and South Gujarat (4 districts) as shown in Figure 1.

Nakshatra Pravesh of Sun: The Kundali at the time of Sun's entry into each Nakshatra is casted for each required place (i.e. district) for the period of Rainy Season. This gives average rainfall for a period of 12-13 days for that Nakshatra, at that place (Varshneya et al., 2008). Table 6 show Performance of Charan wise rainfall prediction in different agroclimatic zones of Gujarat for monsoon 2018.

Nakshatra Charan Pravesh of Sun: The Kundali at the time of Sun's entry into each Nakshatra Charan is casted for each required place (i.e. district) for the period of Rainy Season. This gives average rain for an amount of 2-3 days for that Nakshatra Charan, at that place. Daily rainfall was predicted by using Chandra Nakshatra (Table 7). 
A finer astrological technique of shashthansha (1/60th part of Rashi) kundali was used to distinguish planetary positions/aspects between two adjoining districts.

From each Kundali, various aspects like Mandal of the Lagna, Planets in Saptanadi chakra, Vedhas amongst the planets, and different aspects between planets like Yuti, Pratiyuti, Navapancham Yoga, Kendra Yoga, etc., are taken into account. Importance is given if a planet changes its direction (Vakri or Margi), changes Rashi or Nakshatra, or becomes Asta or Udita.

Similarly, Poornimanta and AamantaKundalis were prepared for predictions. Kundalis was also prepared for eclipses. Effects of sighting comets were also considered.

\section{Meteorological inputs used in Monsoon Research Almanac-2018}

Rainfall probability of getting $\geq 10 \mathrm{~mm}$ rainfall in standard meteorological week (SMW) was calculated by Markov chain model, is given for each district (Data of weekly rainfall for 50-100 years was used for analysis) (Vaidya et al.,2011).

Monthly normal rainfall is given along with projected rainfall for each month for each district.

For 19 districts of Gujarat, monthly maximum and minimum temperature was taken

\section{Computation of Rainfall Projection}

The predicted rainfall intensity on daily basis viz., No rainfall, Low, Medium, Heavy and Very Heavy for each district (26) of Gujarat state from June to October month was used to quantify the rainfall amount of the state. Criteria for quantifying daily rainfall from qualitative prediction for districts under each Agricultural University of the respective region was decided based on frequency analysis for given rainfall intensity and used in the calendar as mentioned in Table 4.

\section{Astro-meteorological principles used in analyzing Kundalis}

Principle No. 1: When many planets are in one Rashi preferably in one nakshatra, it affects the weather. When many planets gather in one rashi with Mars and Sun joining them and Mars is with Rahu, there can be a terrible downpour even if it is not regular monsoon season. When there is concentration of planets in one rashi, the weather begins to fluctuate and with moon joins them, there will be heavy downpour. Cancer, Pisces and Capricorn are full watery signs; Taurus, Leo and Aquarius are half watery signs; Aries, Libra and Scorpio are quarter watery signs while Gemini, Virgo and Sagittarius are not watery signs. Moon and Venus are watery planets. During Winter solstice (Dakshinayana) malefic planets (Saturn, Sun, and Mars) transiting through the Amrita, Jala and Neeranadis, would give rise to ordinary rains. If benefic planets transit the above constellations, there will be plenty of rain.

Principle No. 2 Whatever may be the season, there must be weather-fluctuation when Moon joins Venus or when Moon is fifth or ninth from Venus in the rainy season it causes good rain unless there are factors preventing rains.

Principle No. 3 When Mars transits from one Rashi to another within two days there is a perceptible change in weather and in the rainy season there must be a good rainfall. Mars is the most powerful planet causing rainfall.

Principle No. 4 Similarly, when a major planet such as; Jupiter, Saturn, Rahu or Ketu 
into a fiery, earthy, watery or airy sign, changes a Rashi, it causes momentous events. In case of weather, it must cause a very noticeable change in weather.

Principle No. 5 When planets become retrograde and on the days they become direct there is a change in temperature, humidity and what the meteorologists describe as "disturbance" causing rainfall, etc.

By using criteria given in Table 4 for each district of the respective region, the monthly rainfall projection was computed and it is given in calendar against the normal monthly rainfall.

Formula for Skill Score:

Skill score $(\%)=\frac{\mathrm{YY}+\mathrm{NN}}{\mathrm{YY}+\mathrm{YN}+\mathrm{NY}+\mathrm{NN}}$

Where

YY = Rainfall predicted and actually occurred.

YN = Rainfall Predicted but actually not occurred.

$\mathrm{NY}=$ Rainfall not predicted but actually occurred.

$\mathrm{NN}=$ Rainfall not predicted nor occurred

The skill score (\%) was computed for each month i.e. from June to October for the predictions made for the years 2018. The Yes/No Skill score (\%) was computed using following equation (Singh et al., 1999).Rainfall intensity was predicted for the first time in AAU Monsoon Research Almanac-2007 and has been predicted for 2018. The rainfall projection on monthly basis for each district of Gujarat state was given in Calendar. The validation was done with actual rainfall for each district.

\section{Formula for \% Departure}

$\%$ departure in quantitative $=$

Predicted Rainfall (mm) X 100

Prediction of rainfall - Actual Rainfall (mm)

\section{Results and Discussion}

\section{Salient features of rainfall prediction for Gujarat State-2018}

Overall monsoon rainfall (June to October) will be above normal by $23 \%$ for the state as a whole (Table 5 and Fig. 2), except for Kutch $(-0.5 \%)$, Panchmahal $(-6.3 \%)$ and Mahisagar $(-37 \%)$ districts during June to October, 2018.

This year there will be late onset of monsoon starting from $4^{\text {th }}$ week of June in the state i.e. after $27^{\text {th }}$ June in all four regions of Gujarat.

One or two dry spells observed in most of the districts in this monsoon which will affect the crops.

Chances of getting pre-monsoon and postmonsoon rain at many places during May and November, 2018. There was less rainfall in June, 2018 (-61\% for state as a whole).

From Table 3, there will be highest rainfall in South Gujarat, i.e. $+16.7 \%$, followed by Saurashtra with $+34.7 \%$.

Between June and September, September will get highest amount of rainfall $(+75.8 \%$ followed by August (65.1\%). In October month we have predicted more rainfall but didn't occur.

Validation of rainfall forecast given in Monsoon research Almanac 2018

The validation of rainfall forecast on Yes/No basis indicated that average accuracy was 
$60 \%$ from June to October for state as a whole as shown in Figure 3. Among the four regions average accuracy was highest in South Gujarat $(72.1 \%)$ and lowest in North Gujarat (53.1\%) for the year 2018 as given in Table 9 and Figure 4 to 7.

Validation of rainfall projection with actual rainfall

The district wise daily rainfall is taken from GSDMA website of Government of Gujarat from June to October and validation is done for monthly rainfall projection (prediction) and actual monthly rainfall of the district.
From Table 8 and Figure 8, for year 2018 the average error was $29 \%$ for state as a whole. The most accurate prediction was done for 2018 monsoon with only $-5.2 \%$ error in south Gujarat while it was highest in North Gujarat $(216 \%)$.

Among 19 districts highest skill score a was found in Navsari district $(77 \%)$ of south Gujarat and lowest in Patan district(48\%) of north Gujarat This year we have over predicted rainfall. Due to scarcity of the rainfall (rare events) parts of Gujarat present method gives less accuracy in the case of north Gujarat.

Table.1 Native techniques used for rainfall prediction throughout the country

\begin{tabular}{|c|c|c|}
\hline FLOWERS\&FRUITS & INDICATOR & EXPECTED OUTCOME \\
\hline Bahava & $\begin{array}{l}\text { In melghat,local flower called } \\
\text { Bahava }\end{array}$ & $\begin{array}{c}\text { Blooms } 40 \text { days before } \\
\text { monsoon sets in }\end{array}$ \\
\hline Golden shower tree & Blooms in abundance & $\begin{array}{l}\text { About } 45 \text { days before the } \\
\text { inception of monsoon }\end{array}$ \\
\hline Mango & $\begin{array}{l}\text { abundance of mango brings } \\
\text { flood }\end{array}$ & Very heavy rain \\
\hline Jackfruit & Indicates good rice harvest & Good Monsoon \\
\hline Tamarind trees & Good foliage & Good Monsoon \\
\hline Palash tree & Blooms & Good Monsoon \\
\hline Jamun tree & Ripens & Time to rain \\
\hline Wild cucumbers & Sprout everywhere & Drought \\
\hline Khair trees & Grows bushy & Drought \\
\hline Mango & Flowering in January & Good Monsoon \\
\hline Ebony & New shoots of Ebony & Good Monsoon \\
\hline Bamboo & Profuse Flowering & Good Monsoon \\
\hline Night Flowering Jasmine & Large size of Buds & Good Monsoon \\
\hline Kodoma & Begin to flower & Good Monsoon \\
\hline Thummi plant & Flowers & Good Monsoon \\
\hline Mahuda & Good foliage & Good Monsoon \\
\hline Ber & Heavy flush of fruit & Good Monsoon \\
\hline Darbha grass & Good foliage & Good Monsoon \\
\hline
\end{tabular}


Table.2 Different areas in India have different traditional practices of rainfall prediction

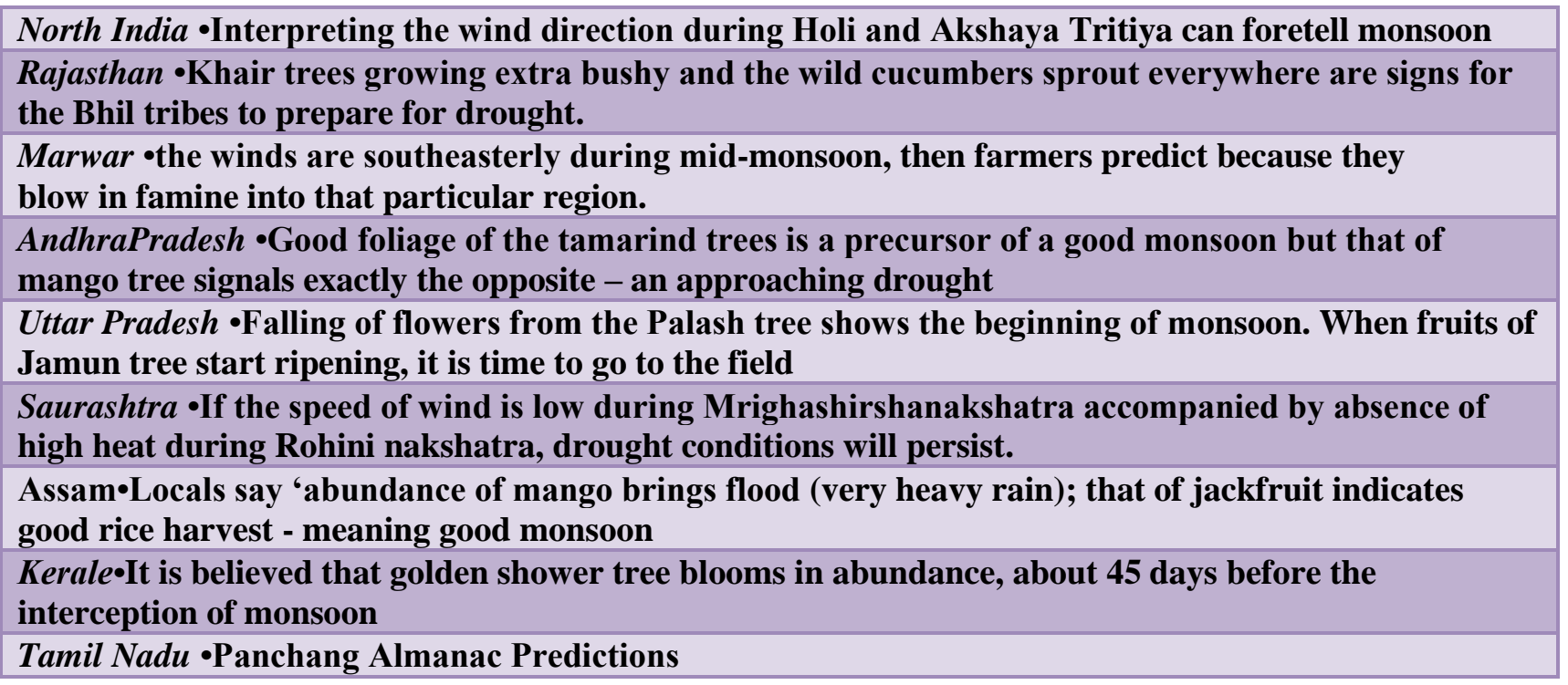

Table.3 Indigenous skill of the tribal community predicate climate

\begin{tabular}{|l|}
\hline Ficus species: Flowering and generation of new leaves indicates near rainfall onset \\
\hline $\begin{array}{l}\text { Butterfly: Appearance of any butterflies indicate early rainfall onset and also gives a prospect } \\
\text { of good season. }\end{array}$ \\
\hline $\begin{array}{l}\text { Ants: Appearance of ants indicate imminent rainfall onset and signifies a prospect for good } \\
\text { season }\end{array}$ \\
\hline Termites: Appearance of any terminates indicate near rainfall onset. \\
\hline Frogs: when frogs start to make a lot noise, it indicate near rainfall onset \\
\hline
\end{tabular}

Table.4 Criteria for quantifying daily rainfall from qualitative prediction in different regions of the state

\begin{tabular}{|c|c|c|c|c|c|c|}
\hline \multirow[t]{2}{*}{ Sr. No. } & \multirow[t]{2}{*}{ Name of Region / SAU } & \multicolumn{5}{|c|}{ Daily Rainfall quantification (mm) } \\
\hline & & No Rain & Low & Medium & Heavy & Very Heavy \\
\hline 1 & Middle Gujarat (AAU, Anand) & 0 & 2 & 10 & 35 & 75 \\
\hline 2 & $\begin{array}{c}\text { North Gujarat } \\
\text { (SardarKrishinagarDantiwada } \\
\text { Agricultural University, SDAU, } \\
\text { Dantiwada) and Saurashtra } \\
\text { (Junagadh Agricultural } \\
\text { University, Junagadh) }\end{array}$ & 0 & 2 & 10 & 30 & 50 \\
\hline 3 & For Kutch district* & 0 & 1 & 6 & 25 & 50 \\
\hline 4 & $\begin{array}{c}\text { South Gujarat (Navsari } \\
\text { Agricultural University (NAU, } \\
\text { Navsari) }\end{array}$ & $\mathbf{0}$ & 6 & 25 & 70 & 100 \\
\hline
\end{tabular}

* Since the rainfall recorded in Kutch is very low, therefore, separate intensity was considered for this district in North Gujarat region 
Table.5 Comparison of Rainfall projection and Normal rainfall for four regions of Gujarat for 2018 (June-October)

\begin{tabular}{|c|c|c|c|c|}
\hline Sr. No & Region & $\begin{array}{c}\text { Rainfall Projection } \\
\text { (June-Oct.) } \mathbf{( m m )}\end{array}$ & $\begin{array}{c}\text { Normal Rainfall } \\
(\mathbf{m m})\end{array}$ & $\begin{array}{c}\text { Rainfall Projection (\%) } \\
\text { departure from normal) }\end{array}$ \\
\hline 1 & Middle Gujarat & 968.3 & 799.8 & 21.1 \\
\hline 2 & North Gujarat & 675.9 & 529.6 & 27.7 \\
\hline 3 & South Gujarat & 1852.3 & 1521.9 & 21.7 \\
\hline 4 & Saurashtra & 836.7 & 674.2 & 24.1 \\
\hline & State & 1083.3 & 881.4 & 22.9 \\
\hline
\end{tabular}

Table.6 Rainfall projection for four regions of Gujarat for 2018 (June-October)

\begin{tabular}{|l|l|c|c|c|}
\hline Sr. No & Region & $\begin{array}{l}\text { Rainfall Projection } \\
\text { (June-Oct.) }(\mathbf{m m})\end{array}$ & \multicolumn{1}{l|}{$\begin{array}{l}\text { Actual Rainfall } \\
(\mathbf{m m})\end{array}$} & $\begin{array}{l}\text { Rainfall Projection (\% } \\
\text { departure from Actual) }\end{array}$ \\
\hline 1 & Middle Gujarat & 968.3 & 656.6 & 47.5 \\
\hline 2 & North Gujarat & 675.3 & 213.8 & 215.9 \\
\hline 3 & South Gujarat & 1852.3 & 1953.0 & -5.2 \\
\hline 4 & Saurashtra & 836.7 & 547.0 & 53.0 \\
\hline & State & 1083.1 & 842.6 & 28.5 \\
\hline
\end{tabular}

Table.7 Performance of Charan wise rainfall prediction in different agro-climatic zones of Gujarat for monsoon 2018

\begin{tabular}{|c|c|c|}
\hline Agro-climatic Zones & Salient features of agreement or disagreement & Ratio Scores \\
\hline $\begin{array}{l}\text { South Gujarat } \\
\text { (heavy rainfall) } \\
\text { (Navsari) }\end{array}$ & $\begin{array}{l}\text { In } 3^{\text {rd }} \text { and } 4^{\text {th }} \text { charan of Adra and Purva Nakshtra and } 1^{\text {st }} \text { and } 2^{\text {nd }} \text { Charan of Uttara } \\
\text { Nakshatra, the actual rainfall was as per forecast. Amount was little bit over } \\
\text { /under estimated. } \\
\text { Less rainfall was recorded in Punarvasu and Magha Nakshatra as compared to } \\
\text { rainfall forecast }\end{array}$ & $76.5 \%$ \\
\hline $\begin{array}{l}\text { South Gujarat } \\
\text { (Surat) }\end{array}$ & $\begin{array}{l}\text { In } 3^{\text {rd }} \text { and } 4^{\text {th }} \text { charan of Adra and Purva Nakshtra and } 1^{\text {st }} \text { and } 2^{\text {nd }} \text { Charan of Uttara } \\
\text { Nakshatra, the actual rainfall was as per forecast. Amount was little bit over } \\
\text { lunder estimated. } \\
\text { Less rainfall was recorded in Punarvasu and Magha Nakshatra as compared to } \\
\text { rainfall forecast }\end{array}$ & $68.8 \%$ \\
\hline $\begin{array}{l}\text { Middle Gujarat } \\
\text { (Anand) }\end{array}$ & $\begin{array}{l}\text { Adra, } 3^{\text {rd }} \text { and } 4^{\text {th }} \text { charan of pushya, } 1^{\text {st }} \text { and } 2^{\text {nd }} \text { charan of Ashlesha, } 3^{\text {rd }} \text { and } 4^{\text {th }} \text { charan } \\
\text { of Purva and } 2^{\text {nd }} \text { charan of UttaraNakshatra, rainfall was recorded as per forecast }\end{array}$ & $55.6 \%$ \\
\hline $\begin{array}{l}\text { North Gujarat } \\
\text { (SK Nagar) }\end{array}$ & $\begin{array}{l}\left.\text { Adra, Pushya ( } 2 \text { to } 4 \text { charan }) \text {, Ashlesha }\left(1^{\text {st }} \text { charan }\right) \text {, Purva ( } 3-4 \text { charan }\right) \text {, Uttara ( } 1 \text { - } \\
2 \text { charan) was found comparable with actual rainfall. Forecasted amount was less } \\
\text { than actual rainfall }\end{array}$ & $54.3 \%$ \\
\hline $\begin{array}{l}\text { North Saurashtra } \\
\text { (Rajkot) }\end{array}$ & $\begin{array}{l}\text { In Adra, Pushya ( } 3-4 \text { charan), Ashlesha ( } 1-2 \text { charan), Magha }\left(1,3 \text {, and } 4^{\text {th }} \text { charan }\right) \text {, } \\
\text { Purva, Uttara (1-2 charan) the actual rainfall was as per forecast with deviation. } \\
\text { In rest of the Nakshatra the rainfall was very less than forecasted. }\end{array}$ & $56.6 \%$ \\
\hline $\begin{array}{l}\text { South Saurashtra } \\
\text { (Junagadh) }\end{array}$ & $\begin{array}{l}\text { In Adra. Pushya (1,3,4charan), Ashlesha ( } 1-3 \text { charan), Purva ( } 2-4 \text { charan) } \\
\text { and Uttara (1-2 charan) the rainfall was as per forecast but with less } \\
\text { quantity. }\end{array}$ & $62.8 \%$ \\
\hline
\end{tabular}


Table.8 Monsoon 2018 -Prediction (\% Departure from Normal)

\begin{tabular}{|c|c|c|c|c|c|c|c|c|}
\hline Region & District & June & July & August & September & October & Season J-S & $\begin{array}{l}\text { Season } \mathrm{J}- \\
\mathrm{O}\end{array}$ \\
\hline \multirow{4}{*}{ South } & Navsari & -74.87 & -2.73 & 42.03 & 112.26 & 21.04 & 13.07 & 13.26 \\
\hline & Surat & -75.98 & -10.11 & 137.13 & 46.48 & 195.88 & 14.58 & 18.42 \\
\hline & Valsad & -96.45 & 34.65 & 17.59 & 63.75 & 151.57 & 10.60 & 13.01 \\
\hline & Dang & -84.48 & 37.54 & 13.70 & 63.53 & 125.75 & 18.61 & 22.01 \\
\hline \multirow[t]{8}{*}{ Middle } & Ahmedabad & -68.6 & -23.8 & 49.4 & -16.0 & -78.0 & 0.7 & 6.5 \\
\hline & Anand & -46.0 & 39.1 & 0.6 & -60.2 & -44.3 & 25.8 & 26.3 \\
\hline & Kheda & -39.0 & 14.7 & 19.3 & -59.7 & -47.9 & 30.1 & 30.6 \\
\hline & Mahisagar & -43.0 & 25.0 & 12.6 & 122.2 & -60.0 & 24.0 & -37.2 \\
\hline & Panchamahal & -85.1 & -12.6 & 6.6 & -27.2 & -36.3 & -7.7 & -6.3 \\
\hline & Dahod & -83.1 & 27.3 & 14.6 & -30.4 & -18.1 & 10.7 & 11.1 \\
\hline & Vadodara & -79.5 & 42.2 & 33.5 & -48.4 & -13.1 & 30.2 & 29.7 \\
\hline & ChotaUdepur & -68.6 & -23.8 & 49.4 & -16.0 & -78.0 & 0.7 & 6.5 \\
\hline \multirow{5}{*}{ North } & & & & & & & & \\
\hline & Gandhinagar & -70.10 & -22.49 & 59.82 & 266.27 & 743.75 & 20.29 & 27.55 \\
\hline & Kutch & 89.87 & -55.56 & -3.59 & 29.29 & 410.64 & -12.48 & -0.48 \\
\hline & Patan & -74.96 & 1.43 & 100.24 & 59.16 & 566.67 & 32.40 & 40.04 \\
\hline & Banaskantha & -74.92 & -15.65 & 60.91 & 70.79 & 419.23 & 16.27 & 22.62 \\
\hline \multirow[t]{3}{*}{ Saurashtra } & Junagadh & -85.26 & -42.53 & 118.80 & 63.12 & 49.47 & -1.07 & 0.64 \\
\hline & Rajkot & -67.78 & -5.03 & 172.46 & 88.82 & 218.18 & 41.32 & 51.47 \\
\hline & Jamnagar & -39.91 & -0.05 & 99.14 & 274.38 & 288.89 & 47.29 & 52.07 \\
\hline \multirow[t]{4}{*}{ Mean } & South Guj. & -82.9 & 14.8 & 52.6 & 71.5 & 123.6 & 14.2 & 16.7 \\
\hline & Middle Guj. & -64.1 & 11.0 & 23.3 & -17.0 & -47.0 & 14.3 & 8.4 \\
\hline & North Guj. & -32.5 & -23.1 & 54.3 & 106.4 & 535.1 & 14.1 & 22.4 \\
\hline & Saurashtra & -64.3 & -15.9 & 130.1 & 142.1 & 185.5 & 29.2 & 34.7 \\
\hline Mean & State & -61.0 & -3.3 & 65.1 & 75.8 & 199.3 & 18.0 & 20.6 \\
\hline
\end{tabular}

Where J-S represent months June to September, J-O represent months June to October 
Table.9 Monsoon 2018 - Skill Score (\%)

\begin{tabular}{|c|c|c|c|c|c|c|c|}
\hline Region & District & June & July & August & September & October & average \\
\hline \multirow[t]{4}{*}{ South } & Navsari & 63.0 & 87.1 & 77.4 & 77.4 & 77.4 & 76.5 \\
\hline & Surat & 77.8 & 77.4 & 67.7 & 56.6 & 64.5 & 68.8 \\
\hline & Valsad & 70.4 & 90.3 & 93.5 & 53.3 & 77.4 & 77.0 \\
\hline & Dang & 70.4 & 71.0 & 93.5 & 46.6 & 48.4 & 66.0 \\
\hline \multirow[t]{8}{*}{ Middle } & Anand & 70.4 & 48.4 & 45.2 & 36.6 & 77.4 & 55.6 \\
\hline & Ahmedabad & 74.1 & 41.9 & 48.4 & 33.3 & 67.7 & 53.1 \\
\hline & Dahod & 74.1 & 45.2 & 51.6 & 53.3 & 80.7 & 61.0 \\
\hline & Kheda & 70.4 & 38.7 & 41.9 & 30.0 & 74.2 & 51.0 \\
\hline & Panchmahal & 70.4 & 61.3 & 35.5 & 33.3 & 77.4 & 55.6 \\
\hline & Vadodara & 70.4 & 58.1 & 45.2 & 40.0 & 74.2 & 57.6 \\
\hline & ChotaUdepur & 77.8 & 67.7 & 54.8 & 26.7 & 74.2 & 60.2 \\
\hline & Mahisaga & 81.5 & 45.2 & 32.3 & 29.0 & 74.2 & 52.4 \\
\hline \multirow{4}{*}{ North } & Gandhinagar & 63.0 & 51.6 & 45.2 & 36.6 & 64.5 & 52.2 \\
\hline & Kutch & 66.7 & 61.3 & 48.4 & 50.0 & 61.3 & 57.5 \\
\hline & Banaskantha & 96.3 & 29.0 & 45.2 & 36.6 & 64.5 & 54.3 \\
\hline & Patan & 69.2 & 29.0 & 41.9 & 40.0 & 61.3 & 48.3 \\
\hline \multirow[t]{3}{*}{ Saurashtra } & Jungadh & 74.1 & 64.5 & 64.5 & 43.3 & 67.7 & 62.8 \\
\hline & Rajkot & 66.7 & 51.6 & 51.6 & 51.6 & 61.3 & 56.6 \\
\hline & Jamnagar & 81.5 & 45.2 & 45.2 & 41.9 & 61.3 & 55.0 \\
\hline \multirow[t]{4}{*}{ Mean } & South Guj. & 70.4 & 81.4 & 83.1 & 58.5 & 66.9 & 72.1 \\
\hline & Middle Guj. & 73.6 & 50.8 & 44.4 & 35.3 & 75.0 & 55.8 \\
\hline & North Guj. & 73.8 & 42.7 & 45.2 & 40.8 & 62.9 & 53.1 \\
\hline & Saurashtra & 74.1 & 53.8 & 53.8 & 45.6 & 63.4 & 58.1 \\
\hline Mean & State & 73.0 & 57.2 & 56.6 & 45.0 & 67.1 & 59.8 \\
\hline
\end{tabular}

Fig.1 Monsoon Research Almanac-2018 for four Agro-climatic Zone Calendar
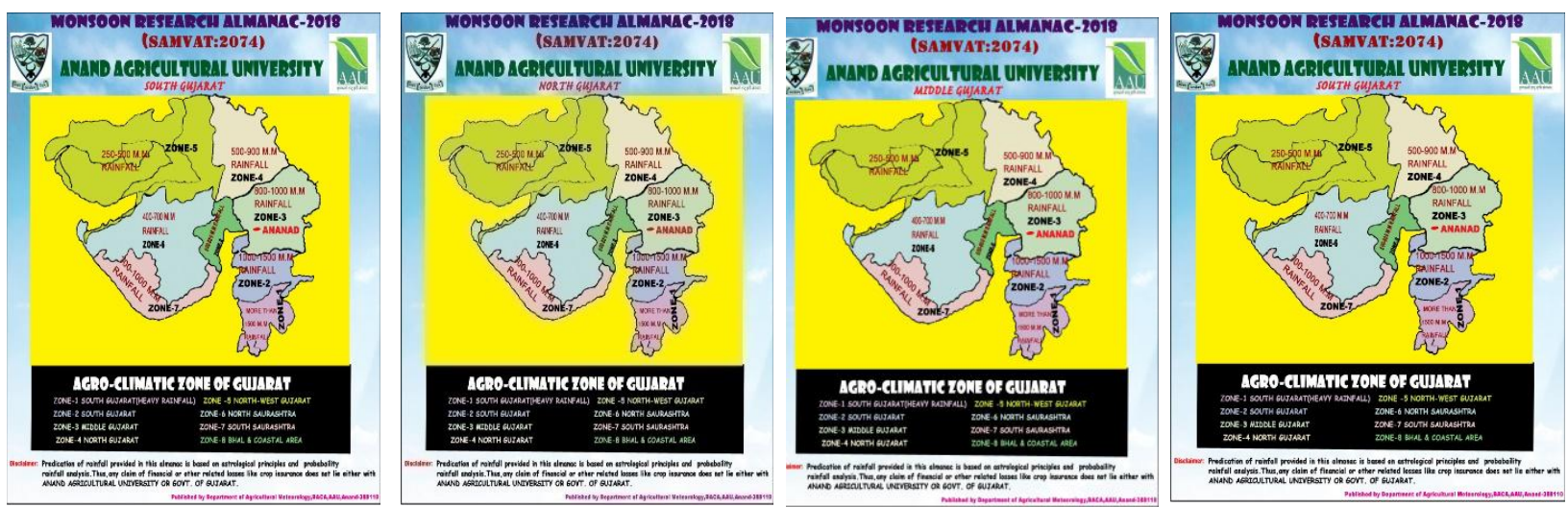
Fig.2 Normal rainfall and Rainfall projection for four regions of Gujarat for 2018 (June-October)

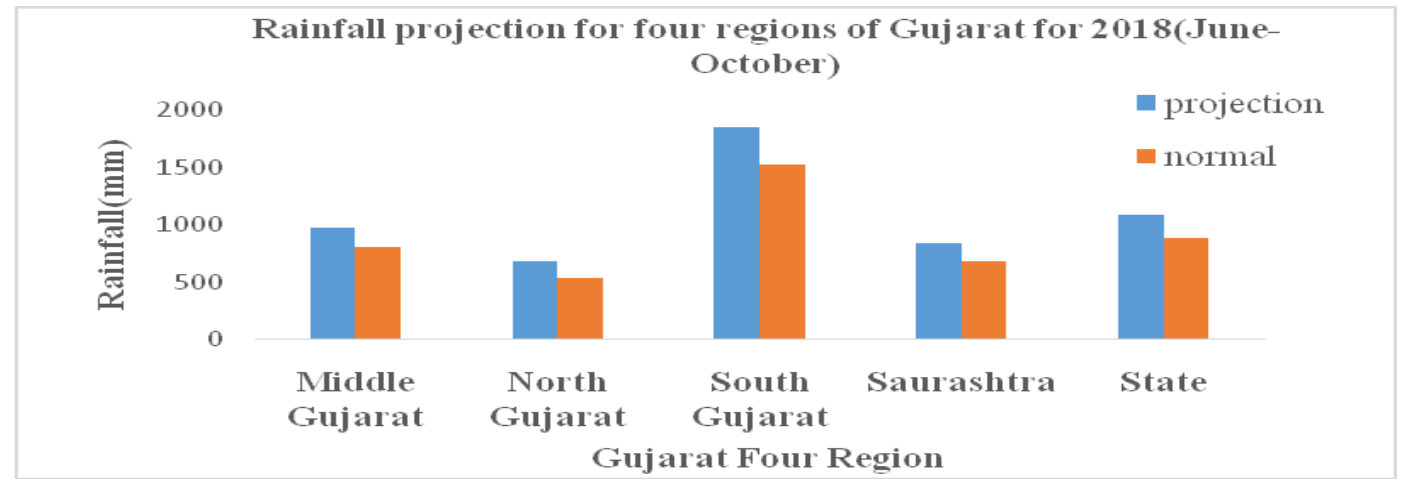

Fig.3 to 7 Gujarat Region Skill score 2018
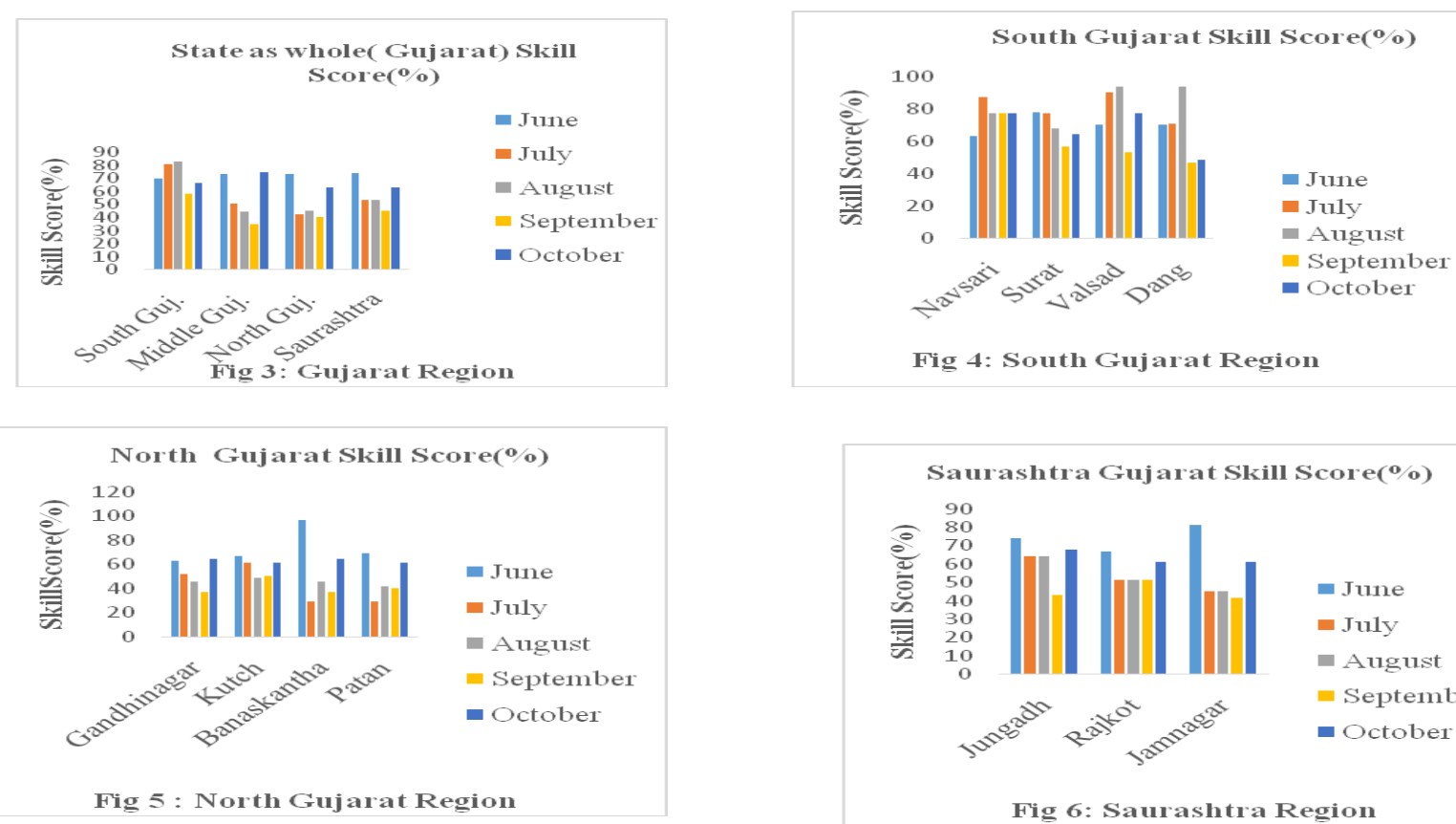

Fig 4: South Gujarat Region

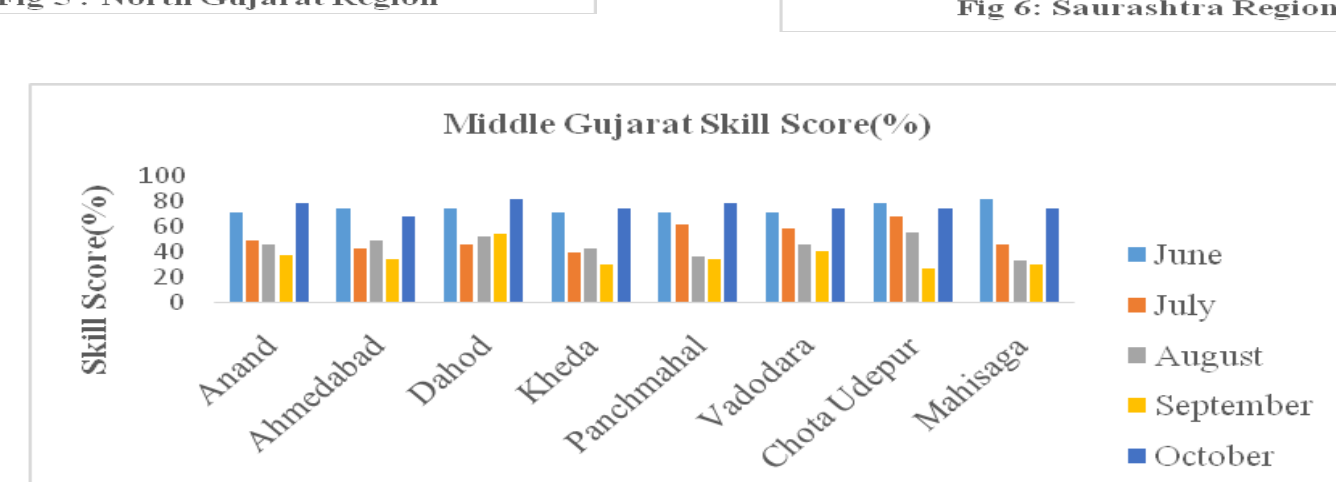

Fig 7: Middle Gujarat Region 
Fig.8 Actual and predicted Rainfall for four regions of Gujarat for 2018 (June-October)

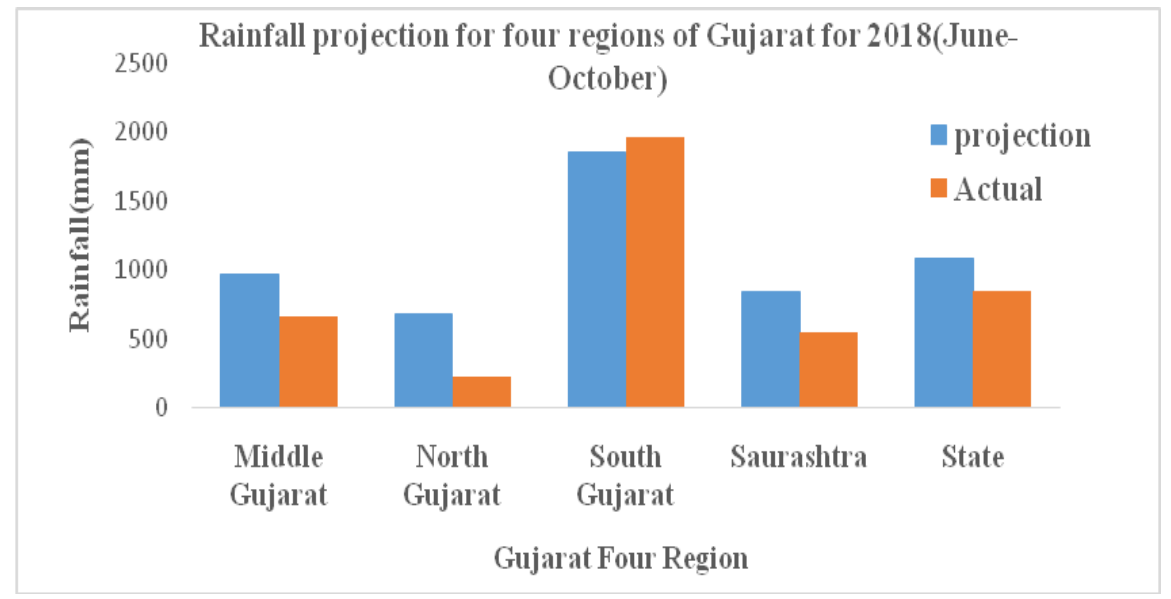

In conclusion, this Astro meteorological technique was accurate for south Gujarat prediction for 2018 monsoon with only $-5.2 \%$ errors while it was highest failure in North Gujarat (216\%). Among 19 districts highest skill score a was found in Navsari district (77\%) of south Gujarat and lowest in Patan district $(48 \%)$ of north Gujarat This year it was over predicted rainfall, due to scarcity of the rainfall (rare events) in parts of Gujarat, the astro meteorological rainfall prediction gave less accuracy in the case of north Gujarat.

Systematic documentation, quantification and subsequent integration of ancient techniques and memories of people is required to make into a conventional weather forecasting system is therefore recommended as one of the strategy that would help to improve the accuracy and reliability of forecasting information under a changing climate.

\section{References}

Anonymous, 2000. Climatic Resources, In Natural Resources of Gujarat- Agroecological data base for regional planning. Joint publication of Soil and Water Management Research Unit, GAU, Navsari and NBSS and LUP,
Regionalcentre Udaipur, GAU and ICAR publication, pp. 23-39.

Angchok, D., and Dubey, V.K., 2005. Traditional method of rainfall prediction through Almanacs in Ladakh, Indian Journal of Traditional Knowledge, Vol 5 No 1, January 2006, pp.145-150.

Kanani, P.R., and Pastakia, A., 1999. Everything is Written in the Sky!: Participatory Meteorological Assessment and Prediction Based on Traditional Beliefs and Indicators in Saurashtra. Journal Asia and International Bioethics, 9, p. 170-6.

Kanani, P.R., Malavia, D.D., and Savaliya, V.J., 2004.Validation of Traditional Meteorological Principles in Saurashtra, India, Conference Proceedings' Bridging Scales and epistemologies: Linking Local Knowledge and Global Science in Multi-Scale Assessments' Alexandria, Egypt, March 17-20.

Nair, K.S., 2004. Role of water in the development of civilization in India: a review of ancient literature, traditional practices and belief, The Basic, A IS Publication 256, December, p. 1 60164. 
Pareek, A., and Trivedi, P.C., 2011, Cultural values and indigenous knowledge of climate change and disaster prediction in Rajasthan, India, Indian Journal of traditional Knowledge, Vol. 10, No. 1, January, p. 184.

Prattipati R., 2016. Metaphilosophy of Creation: Cosmos and beyond Cosmos, Notion Press, 09-Sep-2016 632 pages Santha, S.D., Fraunholz, B., and Unnithan, C., 2010. A societal knowledge management system: harnessing indigenous wisdom to build sustainable predictors for adaptation to climate change, The international journal of climate change: impacts and responses, vol. 2, no. 1, p. 51.

Shekh, A.M., 1989. Agro-climatology of Gujarat, Resource Management Program. ICRISAT, Patancheru, AP, India.

Singh, S.V., Rathore, L.S., Gupta, A.K., and Singh, K.K., 1999. A guide to agrometeorological advisory Services. Department of Science and Technology (DST), Govt. of India Publ., pp. 1-14.
Iyengar, R.N., 2009. Monsoon rainfall cycles as depicted in ancient Sanskrit text. Asian Agri-History 97(3), August 2009. Varshneya, M.C., Vaidya, V.B., Vyas, P., Shekh, A.M., and Karande, B.I., 2008. Validation of Astrometeorological Rainfall forecast for Gujarat. Journal of Agrometeorology, Vol 10, Special issue-part II, pp.345-348.

Varshneya, M.C., Vaidya, V.B., Vyas, P., Chimote, L.D., Damle, K.S., Shekh, A.M., and Karande. B.I. 2009. Forecasting of Rainfall for Gujarat Based on Astro-meteorology. Asian Agri-History, 13(1), pp. 25-37.

Vaidya, V.B., Kedar, D., and Vyas, P., 2011. Report on Validation of rainfall forecast given by AAU Monsoon Research Almanac-2011.Published on International Society for Agrometeorology (INSAM) websitewww.agrometeorology.org., under "Accounts of operational agro meteorology" Dated 18-10-2011, p. 14.

\section{How to cite this article:}

Vaidya, V.B., Suvarna Dhabale, K.S. Damle, L.D. Chimote and Kulshreshtha, M.S. 2019. Astro-Meteorological Rainfall Prediction and Validation for Monsoon 2018 in Gujarat, India. Int.J.Curr.Microbiol.App.Sci. 8(05): 2359-2370. doi: https://doi.org/10.20546/ijcmas.2019.805.279 